\title{
Urbanization and Human Population Favor Species Richness of Alien Birds
}

\author{
Maria Lazarina *, Mariana A. Tsianou $₫$, Georgios Boutsis $₫$, Aristi Andrikou-Charitidou $®$, \\ Elpida Karadimou and Athanasios S. Kallimanis
}

Department of Ecology, Aristotle University, 54124 Thessaloniki, Greece; mtsianou@bio.auth.gr (M.A.T.); gboutsis@bio.auth.gr (G.B.); andrikouc@bio.auth.gr (A.A.-C.); elkaradi@gmail.com (E.K.);

kalliman@bio.auth.gr (A.S.K.)

* Correspondence: mlazarin@bio.auth.gr

Received: 30 December 2019; Accepted: 8 February 2020; Published: 11 February 2020

\begin{abstract}
Human activities like urbanization and agriculture affect spatial biodiversity patterns. The presence and activities of humans richly benefit alien species, but native species usually decline in human-impacted areas. Considering that the richness of alien and native species are inter-related, we explored the effect of human population density, human-related land uses (agricultural and urban), and natural land area on avian (alien and native) species richness of Massachusetts for two time periods using Generalized Additive Models. Avian alien species richness increased with native species richness in both time periods. Despite the predominant role of native species richness as a major driver of alien species richness, human activities play an important additional role in shaping species richness patterns of established aliens. Human-related land uses (urban and agricultural) and human population favored alien species richness in both time periods. Counter to expectations, human activities were also positively associated to native avian species richness. Possible explanations of these patterns may include habitat heterogeneity, increased availability of resources, and reduced predation risk.
\end{abstract}

Keywords: alien species richness; native species richness; breeding birds; human land uses; agricultural area; urban area; Massachusetts

\section{Introduction}

The human-mediated dispersal of species outside their native range, either deliberately or accidentally, has long been part of human history [1]. Global trade and extensive transport networks have increased and are expected to continue to increase the rate of alien species introductions [2-6]. For instance, 900 introductions of bird species have been reported since 2000 [7]. Alien species may pose a major threat to native species richness [8] and ecosystem functioning [9], with collectively significant global socioeconomic impact [10]. Therefore, understanding patterns and drivers of species distribution, as well as of alien diversity emerges as a critical issue for biodiversity conservation [11].

The facilitative role of human population density, human-induced disturbance, and land-use changes on driving establishment and species richness patterns of alien species has been highlighted for different taxonomic groups [12-16]. Humans are not only responsible for the transport of the alien species to new areas (first stage of invasion process), but human activity is also a major driver of the establishment and spread of alien species. Urban landscapes promote alien species richness [15,17-20]. The latter responds along an urbanization gradient (i.e., from downtown to rural residential areas) and exhibits a pattern of increasing species richness from most to least urbanized areas [21], from the edges to the interiors of urban parks [22], and/or from exurban developments to cattle ranges and nature reserves [20]. Human-altered landscapes provide "niche opportunities", increased resources, decreased 
competition, and ideal environmental conditions to alien species [23-25]. Some native species may not be able to exploit ecological opportunities [26] due to a lack of suitable traits to cope with the new environmental conditions of these converted landscapes [27]. For example, human-impacted habitats often harbor alien species because their unique functional traits enable them to adapt to disturbed habitats [28]. On the other hand, land-use changes may provoke the decline of native species richness [29].

Alien species establishment and inter-relation with native species change the community structure, and result in an increase [30] or decrease of total species richness over time [31,32]. The relationship between alien and native species richness is scale-dependent $[33,34]$. The niche competition between native and alien species may result in a negative relationship, especially on small spatial scales [34-36], while both alien and native species may benefit from higher resource availability, especially on larger scales, often resulting in a positive relationship $[37,38]$. Therefore, to better understand the effect of human impact on alien species richness, we must consider the relationship between alien and native species richness.

In the present study, we explored the effect of human population density, human-related land use (agricultural and urban), and natural land uses on avian species richness patterns with an emphasis on the established aliens, using data on breeding birds from Massachusetts for two time periods. Specifically, we address the following questions: (a) Is the relationship between alien and native species richness positive or negative? (b) Do established alien birds benefit from human-dominated land uses, given that human population density and human-altered landscapes are considered to promote alien species richness? (c) Does the effect of human population density and different land uses change over time?

\section{Materials and Methods}

\subsection{Avian Data}

Distribution maps of the breeding birds were obtained by the first and second atlas of Massachusetts [39,40], with surveys taking place in 1968-1972 (MS-1968) and 2007-2011 (MS-2007), respectively. In the atlases, the Massachusetts state was divided into blocks (1/6th of a $7.5 \mathrm{~min}$ of the United States Geological Service quadrangle map) of approximately $25 \mathrm{~km}^{2}$ size. For our analyses, we used only blocks (hereafter called grid cells) that were surveyed in both time periods. Each cell was surveyed for at least 20 hours by volunteers of the Massachusetts Audubon Society. The datasets comprised of the presence-absence data of bird species that showed confirmed breeding. For some species, the mating season was year-round, but most of the surveys took place from April to September. The nomenclature of bird species follows the American Ornithological Society (AOS) Birds of North and Middle America Checklist [41]. Alien bird species were identified following the Global Avian Invasions Atlas (GAVIA), a database of global alien bird distributions [42].

\subsection{Land-Use and Human-Population Data}

Land-use data were obtained by the US Geological Land-Use Survey [43] for 1970s-1980s, and by the 2006 version of the National Land Cover Database (NLCD) [44] for the second time period. Both land-use databases were for the United States and measured $30 \mathrm{~m}$ resolution. The land-use data layers were combined with Atlas grid cells, and we estimated the area of different land uses per grid cell. Then, we calculated the total area per grid cell of three land-use categories: urban, agricultural, and natural land uses. The grouping of different land uses into the three formulated categories is presented in Table S1. Furthermore, human population density per grid cell was estimated using 1980 and 2005 data from HYDE Gridded Population version $3.1[45,46]$. 


\subsection{Statistical Analysis}

We estimated the species richness of native and alien birds per grid cell for the two time periods. To explore if species richness was significantly different between the two periods, we implemented permutational ANOVA separately for alien and native species with the aovp function of the $1 \mathrm{mPerm}$ package [47]. Then, we formulated Generalized Additive Models (GAMs) [48] with the gam function of the $m g c v \mathrm{R}$ package [49], predicting the alien species richness of the different time periods as a function of the area of different land uses (natural, agricultural, and urban) and human population density. Given that native species richness is considered a strong driver of alien species richness, native species richness was included in the GAMs as predictor. Furthermore, we explored the relationship between native species richness, and the area of land uses and human population density using GAMs. In all formulated GAMs, the predictors entered the model as smooth predictor variables with thin-plate regression splines ( 3 knots per spline in order to capture unimodal relationships; Poisson error distribution and log-link function), and the grid cells' co-ordinates were also used as smooth predictors to account for spatial autocorrelation. Finally, we repeated the analysis removing the spatial autocorrelation effect to detect the contribution of predictors to the observed patterns.

\section{Results}

A total of 175 native and 25 alien species were found in the first time period, and 181 native and 24 alien species in the second time period in the state of Massachusetts (Figure 1a,b). Mean native species richness per grid cell was $39.22 \pm 16.74$ species in the first time period, and increased significantly over time to $47.92 \pm 13.25$ species in the second time period (Figure $2 a, p<0.001$ ). Similarly, mean alien species richness increased significantly, from $8.27 \pm 4.16$ to $11.31 \pm 3.15$ species (Figure $2 b, p<0.001$ ). Regarding land uses, agricultural and natural areas shrank. We observed a decrease in approximately $60 \%$ of the grid cells, while urban areas increased in approximately $80 \%$ of the grid cells (Supplementary Material, Figure S1).

The richness of the MS-1968 alien species increased significantly with native species richness, agricultural area, and urban area, while natural area and human population did not exert a significant effect (Figure 3; Supplementary Material, Table S2). The GAM explained $66.20 \%$ of the deviance of alien species richness. By removing the spatial autocorrelation effect, i.e., longitude and latitude as predictors of alien species richness, the explained deviance was approximately 52\% (Supplementary Material, Table S3). In the second time period, the significant positive relationship between alien and native species richness remained. Furthermore, MS-2007 alien species richness increased with human population and exhibited a unimodal relationship with area of natural land uses, while the remaining examined predictors did not show a significant effect (Figure 3; Supplementary Material, Table S2). The explained deviance of the GAM was equal to $58.10 \%$ after accounting for spatial autocorrelation. Removing the spatial autocorrelation effect, the explained deviance was approximately $56 \%$ (Supplementary Material, Table S3).

MS-1968 native species richness increased significantly with the area of the different land uses, while it decreased with human population density (Figure 4; Supplementary Material, Table S4). The GAM explained $35.50 \%$ of deviance after accounting for spatial autocorrelation (explained deviance was approximately $7 \%$ after removing spatial autocorrelation effects; Supplementary Material, Table S5). MS-2007 native species richness decreased with human population density, and followed a unimodal relationship with the area of natural land uses [46.50\% explained deviance after accounting for spatial autocorrelation (Supplementary Material, Table S4), and 13.30\% after removing the spatial effect (Supplementary Material, Table S5)]. 

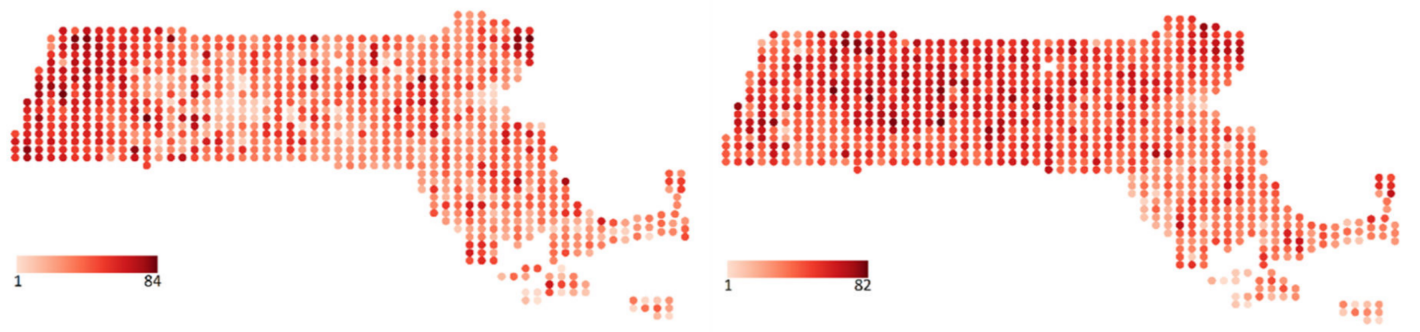

b)
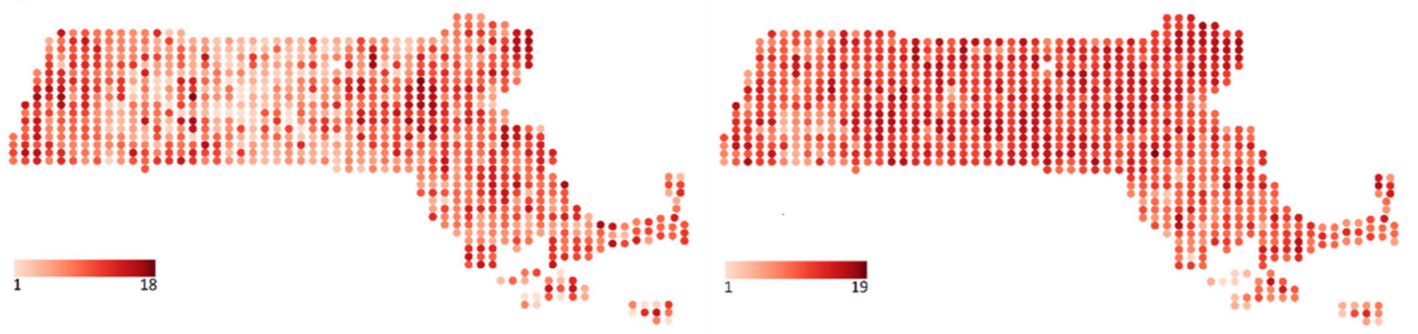

c)
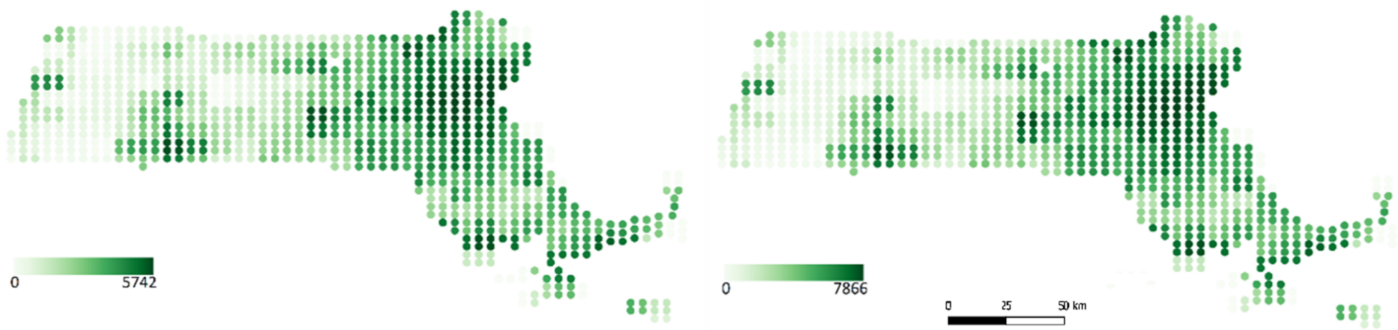

Figure 1. Distribution of (a) native species richness, (b) alien species richness, and (c) human population density in each grid cell (grid cell size approximately $25 \mathrm{~km}^{2}$ ) in the state of Massachusetts for the first time period MS-1968 (left column) and the second time period MS-2007 (right column).
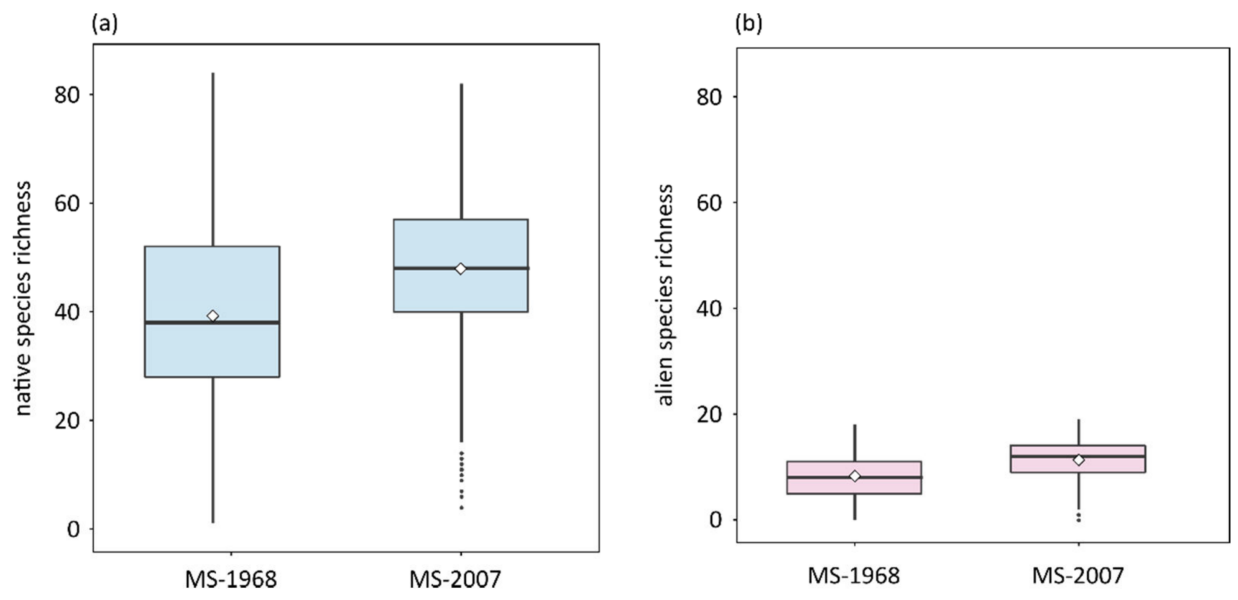

Figure 2. Boxplots of (a) native and (b) alien species richness in the first (MS-1968) and the second (MS-2007) time period of breeding birds of Massachusetts per grid cell (grid cell size approximately 25 $\mathrm{km}^{2}$ ). Diamonds and lines depict mean and median values, respectively. 

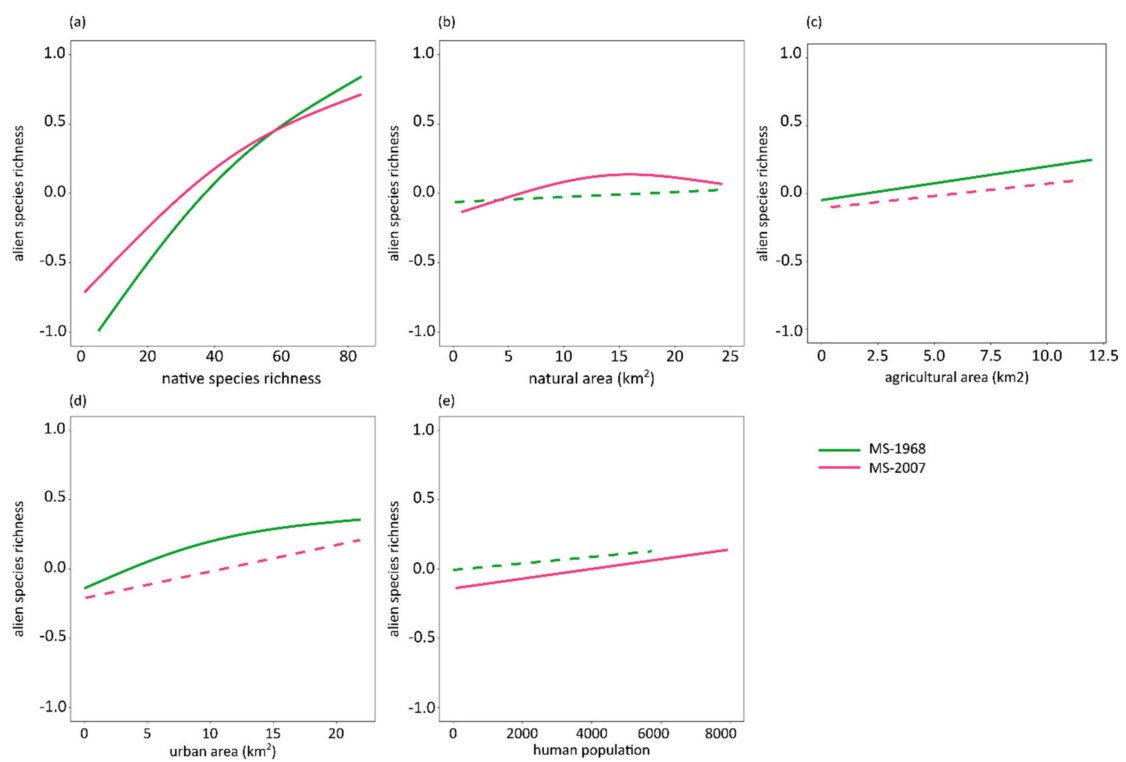

- MS-1968

Figure 3. Effect plots showing results of Generalized Additive Models using as response variable the alien species richness of breeding birds of Massachusetts, and as predictors, native species richness (a), area of different land uses (natural, agricultural, urban; $\mathbf{b}-\mathbf{d}$ ), and human population (e) for the first (MS-1968, green lines) and the second time period (MS-2007, red lines), after accounting for spatial autocorrelation. All predictors entered model as smooth functions; thus, $y$-axis presents mean-centered alien species richness summing up to zero. Significant relationships depicted with solid lines; dashed lines denote non-significant relationships.
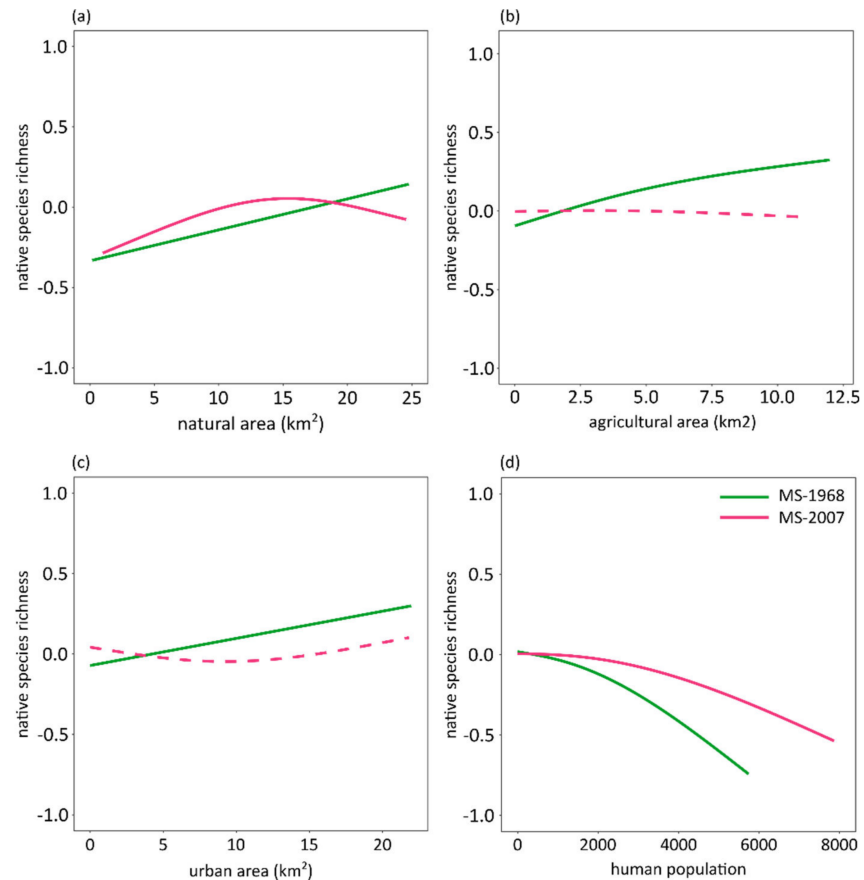

Figure 4. Effect plots showing results of Generalized Additive Models using as response variable the native species richness of breeding birds of Massachusetts, and as predictors area of different land uses (natural, agricultural, urban; a-c) and human population (d) for the first (MS-1968, green lines) and the second time period (MS-2007, red lines) after accounting for spatial autocorrelation. All predictors entered model as smooth functions; thus, $y$-axis presents mean-centered native species richness summing up to zero. Significant relationships depicted with solid lines; dashed lines denote non-significant relationships. 


\section{Discussion}

What are the impacts of human-dominated land uses of urbanization and agriculture on avian richness? The short answer might be that they increase avian abundance, while decreasing avian species richness and simultaneously favoring the introduction and establishment of alien/exotic species $[50,51]$. Our results only partially support this answer. Human-related variables (agriculture, urbanization, and human-population density) were indeed positively associated with alien breeding bird species richness in the State of Massachusetts across both examined time periods (1968-1972 and 2007-2011), but explained only a small proportion of the variance of alien breeding species richness. Native species richness emerged as the strongest predictor of alien species richness in accordance with predictions of the biotic acceptance hypothesis, as previously reported for a similar scale of analysis [33,52]. Although the same human-related variables were positively associated with native bird species richness, human-related variables perhaps favored more alien than native species, as their contribution in driving alien species richness spatial patterns was positive and additive to that of native species richness.

The positive relationship between alien and native species richness, as well as the effect of human-related variables on them, can be explained by different mechanisms. Food availability, especially lack of it during the adverse season of the year, is a major factor regulating avian abundance and diversity $[23,53,54]$. Cities might offer plentiful food resources to birds by importing vast amounts of energy and materials, such as natural vegetation patches, human-generated garbage, and bird feeders $[23,55,56]$. For example, millions of households sustain bird feeders in their gardens, providing huge quantities of supplementary food to birds in North America $[57,58]$. Therefore, by providing food to birds throughout the year, urban areas attract birds, given that birds possess traits to adapt to human-disturbed habitats; this is particularly manifested in alien species, but also true for many common native species $[59,60]$. Furthermore, birds are strongly associated with vegetation structure and composition, and increased habitat heterogeneity might allow both the regional and local coexistence of native and alien birds [29,61]. Human-dominated landscapes, apart from areas unsuitable for birds, also include a wide array of different vegetation types (e.g., hedgerows, gardens, parks, and fields) [62,63]. Moreover, the greater availability of exotic plants in urban and agricultural areas may offer an opportunity for alien bird species that native species may not exploit, thus explaining the additional benefit for established alien species in these areas [64]. On the other hand, natural habitats might be more suitable and preferable to birds, but an extensive contiguous area of a natural type of vegetation (e.g., forest) can support only one functional guild of birds $[65,66]$. Finally, in urban areas, predation rates on birds are significantly lower than those in rural areas [67] due to the lower abundance of bird predators (with the exception of cats, which are generalist predators [68]), and evidence supports birds with lower parasite infestation than those in natural areas [69-71], thus resulting in higher species richness. This may be more evident in alien species for which their successful establishment might be explained by the absence of enemies (e.g., predators, parasites, pathogens) in the new range, i.e., the enemy release hypothesis [72,73].

Human population density played a different role for the two species groups. Native bird species richness was negatively associated with human population density, while alien diversity was positively associated. The positive association of native diversity with urbanization, but negative with population density, may reflect the "luxury effect" [74,75]. Within a city, areas of low population density (often coinciding with areas occupied by higher-income residents) denote areas with more vegetation (either in private gardens or in public parks), with lower traffic congestion, and, consequently, lower levels of noise and air pollution. The higher availability of nesting resources (vegetation) and lower disturbance levels might foster native species richness. Contrarily, alien species are more adapted to human presence and less susceptible to human disturbance [76], perhaps face reduced competition with native species in densely populated areas, and thus appear positively associated with human population density $[16,77]$. 
Our initial expectation that human-related variables would be associated with lower native species richness was not confirmed. It is possible that the increased species richness may be due to the predominance of common widespread species, and masks the loss of phylogenetically or functionally unique species. Another possible explanation could be that native species surviving in relatively high latitudes in this temperate region of the continental USA is characterized by relatively wide environmental tolerances, thus persisting even in human-dominated areas. A third possible explanation might be that the scale of our analysis, i.e., the grid cell size of approximately $25 \mathrm{~km}^{2}$ masks the relationship between native species richness and human-related variables. It is possible that native species richness may not change if the blocks remain relatively the same, even if assuming land-use changes within the block, e.g., agricultural to urban areas, meadows to forests, and forests to urban areas.

In conclusion, we found that human-related land uses promote alien species richness more than native species richness, as human activity perhaps modifies the landscape and habitats, and creates favorable conditions facilitating alien species. However, in terms of species richness, both alien and native species showed positive associations to human land uses, and contrasting results to human population, implying there are a few similarities in drivers that shape the species richness patterns of native and established alien species.

Supplementary Materials: The following are available online at http://www.mdpi.com/1424-2818/12/2/72/s1. Figure S1: Distribution of the coverage of different land uses (natural, agricultural, and urban areas) and the human population of Massachusetts for two time periods, Table S1: Grouping of different land uses of Massachusetts of two time periods into three broad categories: natural, agricultural, and urban, Tables S2 and S3: Results of Generalized Additive Models predicting alien species richness of breeding birds of Massachusetts as function of native species richness, area of different land uses, and human population with and without accounting for spatial autocorrelation, Tables S4 and S5: Results of Generalized Additive Models predicting native species richness of breeding birds of Massachusetts as function of different land uses and human population with and without accounting for spatial autocorrelation.

Author Contributions: M.L. conceived and designed the study; G.B., M.L., A.A.-C., and E.K. contributed to data preparation; M.L. performed statistical analysis; M.L., M.A.T., G.B., A.A.-C., E.K., and A.S.K. contributed to result interpretation and manuscript writing. All authors have read and agreed to the published version of the manuscript.

Funding: Human Resources Development, Education and Lifelong Learning 2014-2020, MIS 5004812

Acknowledgments: This research was cofinanced by Greece and the European Union (European Social Fund, ESF) through Operational Program "Human Resources Development, Education, and Lifelong Learning 2014-2020" in the context of project "Examination of multiple hypotheses on the ecological mechanisms behind alien species invasions" (MIS 5004812).

Conflicts of Interest: The authors declare no conflict of interest.

\section{References}

1. Lewis, S.L.; Maslin, M.A. Defining the anthropocene. Nature 2015, 519, 171-180. [CrossRef] [PubMed]

2. Hulme, P.E. Trade, transport and trouble: Managing invasive species pathways in an era of globalization. J. Appl. Ecol. 2009, 46, 10-18. [CrossRef]

3. Banks, N.C.; Paini, D.R.; Bayliss, K.L.; Hodda, M. The role of global trade and transport network topology in the human-mediated dispersal of alien species. Ecol. Lett. 2015, 18, 188-199. [CrossRef] [PubMed]

4. Seebens, H.; Blackburn, T.M.; Dyer, E.E.; Genovesi, P.; Hulme, P.E.; Jeschke, J.M.; Pagad, S.; Pyšek, P.; van Kleunen, M.; Winter, M. Global rise in emerging alien species results from increased accessibility of new source pools. Proc. Natl. Acad. Sci. USA 2018, 115, E2264-E2273. [CrossRef]

5. Blackburn, T.M.; Gaston, K.J. Abundance, biomass and energy use of native and alien breeding birds in Britain. Biol. Invasions 2018, 20, 3563-3573. [CrossRef]

6. Seebens, H.; Blackburn, T.M.; Dyer, E.E.; Genovesi, P.; Hulme, P.E.; Jeschke, J.M.; Pagad, S.; Pyšek, P.; Winter, M.; Arianoutsou, M. No saturation in the accumulation of alien species worldwide. Nat. Commun. 2017, 8, 14435. [CrossRef] 
7. Dyer, E.E.; Cassey, P.; Redding, D.W.; Collen, B.; Franks, V.; Gaston, K.J.; Jones, K.E.; Kark, S.; Orme, C.D.L.; Blackburn, T.M. The global distribution and drivers of alien bird species richness. PLoS Biol. 2017, 15, e2000942. [CrossRef]

8. Vilà, M.; Basnou, C.; Pyšek, P.; Josefsson, M.; Genovesi, P.; Gollasch, S.; Nentwig, W.; Olenin, S.; Roques, A.; Roy, D. How well do we understand the impacts of alien species on ecosystem services? A pan-European, cross-taxa assessment. Front. Ecol. Environ. 2010, 8, 135-144. [CrossRef]

9. Vilà, M.; Espinar, J.L.; Hejda, M.; Hulme, P.E.; Jarošík, V.; Maron, J.L.; Pergl, J.; Schaffner, U.; Sun, Y.; Pyšek, P. Ecological impacts of invasive alien plants: A meta-analysis of their effects on species, communities and ecosystems. Ecol. Lett. 2011, 14, 702-708. [CrossRef]

10. Simberloff, D.; Martin, J.-L.; Genovesi, P.; Maris, V.; Wardle, D.A.; Aronson, J.; Courchamp, F.; Galil, B.; García-Berthou, E.; Pascal, M. Impacts of biological invasions: What's what and the way forward. Trends Ecol. Evol. 2013, 28, 58-66. [CrossRef]

11. Duncan, R.P.; Cassey, P.; Pigot, A.L.; Blackburn, T.M. A general model for alien species richness. Biol. Invasions 2019, 21, 2665-2677. [CrossRef]

12. Davies, R.G.; Orme, C.D.L.; Olson, V.; Thomas, G.H.; Ross, S.G.; Ding, T.-S.; Rasmussen, P.C.; Stattersfield, A.J.; Bennett, P.M.; Blackburn, T.M. Human impacts and the global distribution of extinction risk. Proc. R. Soc. B Biol. Sci. 2006, 273, 2127-2133. [CrossRef]

13. Lockwood, J.L.; Hoopes, M.F.; Marchetti, M.P. Invasion Ecology; John Wiley and Sons: Hoboken, NJ, USA, 2013.

14. Leprieur, F.; Beauchard, O.; Blanchet, S.; Oberdorff, T.; Brosse, S. Fish invasions in the world's river systems: When natural processes are blurred by human activities. PLoS Biol. 2008, 6, e28.

15. Pyšek, P.; Bacher, S.; Chytrý, M.; Jarošík, V.; Wild, J.; Celesti-Grapow, L.; Gassó, N.; Kenis, M.; Lambdon, P.W.; Nentwig, W. Contrasting patterns in the invasions of European terrestrial and freshwater habitats by alien plants, insects and vertebrates. Glob. Ecol. Biogeogr. 2010, 19, 317-331. [CrossRef]

16. Chiron, F.; Shirley, S.; Kark, S. Human-related processes drive the richness of exotic birds in Europe. Proc. R. Soc. B Biol. Sci. 2008, 276, 47-53. [CrossRef] [PubMed]

17. Aronson, M.F.; Handel, S.N.; La Puma, I.P.; Clemants, S.E. Urbanization promotes non-native woody species and diverse plant assemblages in the New York metropolitan region. Urban Ecosyst. 2015, 18, 31-45. [CrossRef]

18. Kühn, I.; Klotz, S. Urbanization and homogenization-comparing the floras of urban and rural areas in Germany. Biol. Conserv. 2006, 127, 292-300. [CrossRef]

19. Cadotte, M.W.; Yasui, S.L.E.; Livingstone, S.; MacIvor, J.S. Are urban systems beneficial, detrimental, or indifferent for biological invasion? Biol. Invasions 2017, 19, 3489-3503. [CrossRef]

20. Maestas, J.D.; Knight, R.L.; Gilgert, W.C. Biodiversity across a rural land-use gradient. Conserv. Biol. 2003, 17, 1425-1434. [CrossRef]

21. Clergeau, P.; Savard, J.-P.L.; Mennechez, G.; Falardeau, G. Bird abundance and diversity along an urban-rural gradient: A comparative study between two cities on different continents. Condor 1998, 100, 413-425. [CrossRef]

22. Fernandez-Juricic, E. Avian spatial segregation at edges and interiors of urban parks in Madrid, Spain. Biodivers. Conserv. 2001, 10, 1303-1316. [CrossRef]

23. McKinney, M.L. Urbanization as a major cause of biotic homogenization. Biol. Conserv. 2006, 127, $247-260$. [CrossRef]

24. Kark, S.; Allnutt, T.F.; Levin, N.; Manne, L.L.; Williams, P.H. The role of transitional areas as avian biodiversity centres. Glob. Ecol. Biogeogr. 2007, 16, 187-196. [CrossRef]

25. Shea, K.; Chesson, P. Community ecology theory as a framework for biological invasions. Trends Ecol. Evol. 2002, 17, 170-176. [CrossRef]

26. Sol, D.; Bartomeus, I.; Griffin, A.S. The paradox of invasion in birds: Competitive superiority or ecological opportunism? Oecologia 2012, 169, 553-564. [CrossRef]

27. McKinney, M.L. Urbanization, Biodiversity, and ConservationThe impacts of urbanization on native species are poorly studied, but educating a highly urbanized human population about these impacts can greatly improve species conservation in all ecosystems. Bioscience 2002, 52, 883-890. [CrossRef] 
28. Sax, D.F.; Brown, J.H. The paradox of invasion. Glob. Ecol. Biol. 2000, 9, 363-371. [CrossRef]

29. McKinney, M.L. Effects of urbanization on species richness: A review of plants and animals. Urban Ecosyst. 2008, 11, 161-176. [CrossRef]

30. Traveset, A.; Richardson, D.M. Mutualistic interactions and biological invasions. Annu. Rev. Ecol. Evol. Syst. 2014, 45, 89-113. [CrossRef]

31. Jauni, M.; Ramula, S. Meta-analysis on the effects of exotic plants on the fitness of native plants. Perspect. Plant Ecol. Evol. Syst. 2015, 17, 412-420. [CrossRef]

32. Sugiura, S. Impacts of introduced species on the biota of an oceanic archipelago: The relative importance of competitive and trophic interactions. Ecol. Res. 2016, 31, 155-164. [CrossRef]

33. Fridley, J.D.; Stachowicz, J.; Naeem, S.; Sax, D.; Seabloom, E.; Smith, M.; Stohlgren, T.; Tilman, D.; Holle, B.V. The invasion paradox: Reconciling pattern and process in species invasions. Ecology 2007, 88, 3-17. [CrossRef]

34. Tomasetto, F.; Duncan, R.P.; Hulme, P.E. Resolving the invasion paradox: Pervasive scale and study dependence in the native-alien species richness relationship. Ecol. Lett. 2019, 22, 1038-1046. [CrossRef] [PubMed]

35. Elton, C.S. The Ecology of Invasions by Plants and Animals; Methuen: London, UK, 1958.

36. Levine, J.M.; Adler, P.B.; Yelenik, S.G. A meta-analysis of biotic resistance to exotic plant invasions. Ecol. Lett. 2004, 7, 975-989. [CrossRef]

37. Stohlgren, T.J.; Barnett, D.T.; Kartesz, J.T. The rich get richer: Patterns of plant invasions in the United States. Front. Ecol. Environ. 2003, 1, 11-14. [CrossRef]

38. Poessel, S.A.; Beard, K.H.; Callahan, C.M.; Ferreira, R.B.; Stevenson, E.T. Biotic acceptance in introduced amphibians and reptiles in Europe and North America. Glob. Ecol. Biogeogr. 2013, 22, 192-201. [CrossRef]

39. Petersen, W.R.; Meservey, W.R. Massachusetts Breeding Bird Atlas; University of Massachusetts Press: Amherst, MA, USA, 2003.

40. Kamm, M. The Massachusetts Breeding Bird Atlas 2; Mass Audubon: Topsfield, MA, USA, 2013.

41. Chesser, R.; Burns, K.; Cicero, C.; Dunn, J.; Kratter, A.; Lovette, I.; Rasmussen, P.; Remsen, J., Jr.; Stotz, D.; Winger, B. Check-List of North American Birds (Online); American Ornithological Society: Chicago, IL, USA, 2018.

42. Dyer, E.E.; Redding, D.W.; Blackburn, T.M. The global avian invasions atlas, a database of alien bird distributions worldwide. Sci. Data 2017, 4, 170041. [CrossRef]

43. Price, C.V.; Nakagaki, N.; Hitt, K.J.; Clawges, R. Enhanced Historical Land-Use and Land-Cover Data Sets of the US Geological Survey; US Department of the Interior, US Geological Survey. U.S. Geological Survey digital data series 240. 2007. Available online: http://pubs.usgs.gov/ds/2006/240/ (accessed on 28 September 2019).

44. Fry, J.A.; Xian, G.; Jin, S.; Dewitz, J.A.; Homer, C.G.; Yang, L.; Barnes, C.A.; Herold, N.D.; Wickham, J.D. Completion of the 2006 national land cover database for the conterminous United States. PE RS Photogramm. Eng. Remote Sens. 2011, 77, 858-864.

45. Klein Goldewijk, K.; Beusen, A.; Janssen, P. Long-term dynamic modeling of global population and built-up area in a spatially explicit way: HYDE 3.1. Holocene 2010, 20, 565-573. [CrossRef]

46. Klein Goldewijk, K.; Beusen, A.; Van Drecht, G.; De Vos, M. The HYDE 3.1 spatially explicit database of human-induced global land-use change over the past 12,000 years. Glob. Ecol. Biogeogr. 2011, 20, 73-86. [CrossRef]

47. Wheeler, B.; Torchiano, M. lmPerm: Permutation Tests for Linear Models. R Package Version 1.1-2. Available online: http://CRAN.R-project.org/package=lmPerm (accessed on 25 August 2013).

48. Hastie, T.; Tibshirani, R. Exploring the nature of covariate effects in the proportional hazards model. Biometrics 1990, 46, 1005-1016. [CrossRef]

49. Wood, S.N. mgcv: GAMs and generalized ridge regression for R. R News 2001, 1, 20-25.

50. Chace, J.F.; Walsh, J.J. Urban effects on native avifauna: A review. Landsc. Urban Plan. 2006, 74, 46-69. [CrossRef]

51. Ibáñez-Álamo, J.D.; Rubio, E.; Benedetti, Y.; Morelli, F. Global loss of avian evolutionary uniqueness in urban areas. Glob. Chang. Biol. 2017, 23, 2990-2998. [CrossRef] [PubMed]

52. Jeschke, J.M. General hypotheses in invasion ecology. Divers. Distrib. 2014, 20, 1229-1234. [CrossRef] 
53. Siriwardena, G.M.; Stevens, D.K.; Anderson, G.Q.; Vickery, J.A.; Calbrade, N.A.; Dodd, S. The effect of supplementary winter seed food on breeding populations of farmland birds: Evidence from two large-scale experiments. J. Appl. Ecol. 2007, 44, 920-932. [CrossRef]

54. Siriwardena, G.M.; Baillie, S.R.; Wilson, J.D. Temporal variation in the annual survival rates of six granivorous birds with contrasting population trends. Ibis 1999, 141, 621-636. [CrossRef]

55. Jones, D. The Birds at My Table: Why We Feed wild Birds and Why it Matters; Cornell University Press: Ithaca, MY, USA, 2018.

56. Oro, D.; Genovart, M.; Tavecchia, G.; Fowler, M.S.; Martínez-Abraín, A. Ecological and evolutionary implications of food subsidies from humans. Ecol. Lett. 2013, 16, 1501-1514. [CrossRef]

57. Robb, G.N.; McDonald, R.A.; Chamberlain, D.E.; Bearhop, S. Food for thought: Supplementary feeding as a driver of ecological change in avian populations. Front. Ecol. Environ. 2008, 6, 476-484. [CrossRef]

58. Galbraith, J.A.; Beggs, J.R.; Jones, D.N.; Stanley, M.C. Supplementary feeding restructures urban bird communities. Proc. Natl. Acad. Sci. USA 2015, 112, E2648-E2657. [CrossRef]

59. Ciach, M.; Fröhlich, A. Habitat type, food resources, noise and light pollution explain the species composition, abundance and stability of a winter bird assemblage in an urban environment. Urban Ecosyst. 2017, 20, 547-559. [CrossRef]

60. Plummer, K.E.; Risely, K.; Toms, M.P.; Siriwardena, G.M. The composition of British bird communities is associated with long-term garden bird feeding. Nat. Commun. 2019, 10,1-8. [CrossRef]

61. Peng, S.; Kinlock, N.L.; Gurevitch, J.; Peng, S. Correlation of native and exotic species richness: A global meta-analysis finds no invasion paradox across scales. Ecology 2019, 100, e02552. [CrossRef]

62. Wania, A.; Kühn, I.; Klotz, S. Plant richness patterns in agricultural and urban landscapes in Central Germany-Spatial gradients of species richness. Landsc. Urban Plan. 2006, 75, 97-110. [CrossRef]

63. Oliveira Hagen, E.; Hagen, O.; Ibáñez-Álamo, J.D.; Petchey, O.L.; Evans, K.L. Impacts of urban areas and their characteristics on avian functional diversity. Front. Ecol. Evol. 2017, 5, 84. [CrossRef]

64. Faeth, S.H.; Bang, C.; Saari, S. Urban biodiversity: Patterns and mechanisms. Ann. N. Y. Acad. Sci. 2011, 1223, 69-81. [CrossRef] [PubMed]

65. Daniel Kissling, W.; Böhning-Gaese, K.; Jetz, W. The global distribution of frugivory in birds. Glob. Ecol. Biogeogr. 2009, 18, 150-162. [CrossRef]

66. Kissling, W.D.; Sekercioglu, C.H.; Jetz, W. Bird dietary guild richness across latitudes, environments and biogeographic regions. Glob. Ecol. Biogeogr. 2012, 21, 328-340. [CrossRef]

67. Eötvös, C.B.; Magura, T.; Lövei, G.L. A meta-analysis indicates reduced predation pressure with increasing urbanization. Landsc. Urban Plan. 2018, 180, 54-59. [CrossRef]

68. Kauhala, K.; Talvitie, K.; Vuorisalo, T. Free-ranging house cats in urban and rural areas in the north: Useful rodent killers or harmful bird predators? Folia Zool. 2015, 64, 45-56. [CrossRef]

69. Geue, D.; Partecke, J. Reduced parasite infestation in urban Eurasian blackbirds (Turdus merula): A factor favoring urbanization? Can. J. Zool. 2008, 86, 1419-1425. [CrossRef]

70. Bobby Fokidis, H.; Greiner, E.C.; Deviche, P. Interspecific variation in avian blood parasites and haematology associated with urbanization in a desert habitat. J. Avian Biol. 2008, 39, 300-310. [CrossRef]

71. Calegaro-Marques, C.; Amato, S.B. Urbanization breaks up host-parasite interactions: A case study on parasite community ecology of Rufous-bellied Thrushes (Turdus rufiventris) along a rural-urban gradient. PLoS ONE 2014, 9, e103144. [CrossRef] [PubMed]

72. Colautti, R.I.; Ricciardi, A.; Grigorovich, I.A.; MacIsaac, H.J. Is invasion success explained by the enemy release hypothesis? Ecol. Lett. 2004, 7, 721-733. [CrossRef]

73. Heger, T.; Jeschke, J.M. The enemy release hypothesis as a hierarchy of hypotheses. Oikos 2014, 123, 741-750. [CrossRef]

74. Strohbach, M.W.; Haase, D.; Kabisch, N. Birds and the city: Urban biodiversity, land use, and socioeconomics. Ecol. Soc. 2009, 14, 2. [CrossRef]

75. Leong, M.; Dunn, R.R.; Trautwein, M.D. Biodiversity and socioeconomics in the city: A review of the luxury effect. Biol. Lett. 2018, 14, 20180082. [CrossRef] 
76. Barnagaud, J.-Y.; Barbaro, L.; Papaix, J.; Deconchat, M.; Brockerhoff, E.G. Habitat filtering by landscape and local forest composition in native and exotic New Zealand birds. Ecology 2014, 95, 78-87. [CrossRef]

77. Spear, D.; Foxcroft, L.C.; Bezuidenhout, H.; McGeoch, M.A. Human population density explains alien species richness in protected areas. Biol. Conserv. 2013, 159, 137-147. [CrossRef]

(C) 2020 by the authors. Licensee MDPI, Basel, Switzerland. This article is an open access article distributed under the terms and conditions of the Creative Commons Attribution (CC BY) license (http://creativecommons.org/licenses/by/4.0/). 